\title{
Influence of temperature on the growth of fecal coliform
}

\author{
Md. Shaheduzzaman, Md. Sayedur Rahman and Ifra Tun Nur* \\ Department of Microbiology, Stamford University Bangladesh, 51 Siddeswari Road, Dhaka 1217, Bangladesh \\ Received 13 May 2016/Accepted 18 June 2016

\begin{abstract}
The cellular response against environmental stresses is one of the most highly conserved regulatory features among all organisms. The exposure of cells to stresses such as heat shock leads to the accumulation of partially and fully denatured proteins that interfere with normal cellular function. Present study was designed to examine the growth and physiology of Escherichia coli at different temperatures in our laboratory condition. With a previous observation of Escherichia coli growth cessation by the increase in temperature on different culture media, current study further extended the examination of the influence of temperature on the growth behavior of fecal coliform on minimal media, a slight retardation in the colony and cell morphology was noticed for fecal coliform at $47^{\circ} \mathrm{C}$ within 36 hours to 72 hours of incubation. Consistent result was also found in spot test for fecal species at $45^{\circ} \mathrm{C}$.
\end{abstract}

Key words: Escherichia coli; Growth; Heat shock; Cell aggregates

A considerable number of the heat-shock proteins (HSPs) have been found to be reported so far which gets started while providing feedback to a group of stress factors principally including shock induced from heat, paucity of nutrients, osmotic pressure shock, toxic chemicals and many other factors like this (1-9). There has been intense investigation on the up-regulation or hyper-activity of the genes which are responsible for encoding the HSPs during an increase in the temperature (10-11). Different bacterial species have different strategies of producing HSPs. For example, in Bacillus cells, CspB and CspE are found to be in function, whereas in Escherichia coli and Salmonella spp., GroEL and DnaK protein amounts have been found to be in an increase (10-13). These are chaperone mediated defense mechanisms and can vary on the spp. There has been reporting of an almost similar mode of cellular biochemical network in Pseudomonas spp. and E. $\operatorname{coli}(8,9,14-18)$.

The earlier studies that we have performed so far has provided valuable information on the genetic regulation of the generation of oxidative stress response and the influence of the temperature up-shift on this response in E. coli $(7,8)$. The physiological changes and influences that comes from internal and external oxidative stress in different bacterial cells has been a necessity to continue this study $(7,8,18-22)$. Our earlier studies have confirmed the fact that E. coli (SUBE01) and Pseudomonas spp. (SUBP01) could not retain the

"Corresponding Author: Mailing address. Ifra Tun Nur, Department of Microbiology, Stamford University Bangladesh, 51 Siddeswari Road, Dhaka 1217, Bangladesh, Bangladesh; E-mail: tun.ifra@yahoo.com. ability to form colonies on the agar plates when they were exposed to oxidative stress. It should be stated that raise of temperature can have a close impact on the occurrence of oxidative stress $(5,7,21,22)$.

The findings from the previous studies showing the various cellular activities of microbial cells to mitigate temperature and oxidative stress galvanized us to investigate the effect of high temperature on the viable cell number of $E$. coli.

\section{MATERIALS AND METHODS}

Bacterial stain, medium and culture condition. Laboratory stock cultures of E.coli were used in this study. Minimal agar (MA) was used for the assay of cultureability (19). After 24 hour incubation on nutrient agar plates at $37{ }^{\circ} \mathrm{C}$, one loopful of bacterial culture was introduced into $5 \mathrm{ml}$ nutrient broth followed by 0 rpm (rotation per minute) at $37{ }^{\circ} \mathrm{C}$ for $4-6$ hours (pre-culture). After adjusting optical density of the pre-culture at $600 \mathrm{~nm}\left(\mathrm{OD}_{600}\right)$ to $0.1,30 \mu \mathrm{L}$ each was introduced into 2 different sets of $30 \mathrm{ml}$ of Minimal broth and incubated at, $45^{\circ} \mathrm{C}$, $47^{\circ} \mathrm{C}$ at static condition $(0 \mathrm{rpm})$. At every 12 hours cell growth was monitored by measuring $\mathrm{OD}_{600}$, and the formation of colony forming units (CFUs) were estimated by counting the colonies up to 72 hours at every 24 hour intervals $(8,19,21,23)$. All the experiments were executed three times.

Microscopy. For the observation of cell morphology and arrangements, simple staining (Crystal Violet, Hucker's Solution) was applied as previously done (23). An aliquot of $10 \mu \mathrm{l}$ from each bacterial culture suspension were removed at 12 hours intervals and the shape and organization of cells were observed under light microscope (Optima Biological Mi-croscope G206, manufactured in Taiwan) at $1000 \times$ magnification (23).

Spot test. As described previously, each of the bacterial culture suspensions were serially diluted in $9 \mathrm{ml}$ nutrient broth to obtain up to $10^{-4}$ fold dilution $(19,23)$. From each dilution, an aliquot of $5 \mu \mathrm{l}$ was dropped on to the NA plates, dried off for 15 minutes, and finally the plates were incubated at $37^{\circ} \mathrm{C}$ for 24 hours. Spotting was done at every 12 hours of growth $(19,23)$.

\section{RESULTS AND DISCUSSIONS}

Previously our research group extensively worked on oxidative stress, nutrient starvation, addition of different nutrient sources for the growth response of different 
different bacteria (19-23). As a consequence, temperature stress is a prime subject for our study. In our earlier work growth of $E$. coli was suppressed at the lower temperatures (both at $25{ }^{\circ} \mathrm{C}$ and $30{ }^{\circ} \mathrm{C}$ ) and drastically at $45^{\circ} \mathrm{C}$ because of generation of reactive oxygen species (ROS) as discussed previously $(18,19)$. In this regard the present study was undertaken to observe the response of fecal coliform under temperature stress.

Growth retardation of Escherichia coli upon heat shock. In minimal media, no significant changes were observed in cell turbidity (Figure 1) as well as in colony forming units (cfu) at $45{ }^{\circ} \mathrm{C}$. It is known that a set of indispensable called thermotolerant genes are expressed for the growth of $E$. coli (fecal origin) at high temperature (20). However, growth retardation of bacteria observed after 72 hours of incubation periods. Morphological changes of Escherichia coli. In cohort with the previous findings of growth pattern, morphological change was documented for fecal coliform when they were subjected to grow at different temperature in Minimal agar and up to 72 hours of incubation at $45^{\circ} \mathrm{C}$ (Figure 2). They were found to be slightly shrunken after 48 hours and swollen at 60 hours. Slightly elongated cells were also found from minimal broth culture of E.coli at $47^{\circ} \mathrm{C}$ after 24 hours. while the cells were transformed into thread like structure at 60 hours of incubation. It has been documented that at a very short exposure of $43{ }^{\circ} \mathrm{C}$ can up regulated 343 heat shock genes and these genes induce major HSPs, including the main cellular chaperone machineries of GroEL and DnaK, ATP-dependent proteases of Lon, HslUV, Clp and FtsH (HflB), periplasmic protease DegP, and other proteins involved in protein folding, refolding, quality control and degradation $(24,25)$.

Confirmative demonstration of loss of culturability of Escherichia coli. The observation of the sharp decline in cultivable cell population fraction as well as the morphological changes due to heat stress, led to further cross check the stressed physiology of the cells through spot tests. As shown in Figure 3, at $47{ }^{\circ} \mathrm{C}$ after 48 hours, growth of $E$. coli was found to be significantly inhibited compare to the $45{ }^{\circ} \mathrm{C}$. Afterward at 72 hours, the bacterium treated with high temperature was completely unable to form colonies, consistent to the growth studies (Figures 1 \& 3).

\section{CONCLUSION}

The capacity of Escherichia coli to mount a multifaceted response to the wide variety of stresses encountered by these organisms in vivo and in

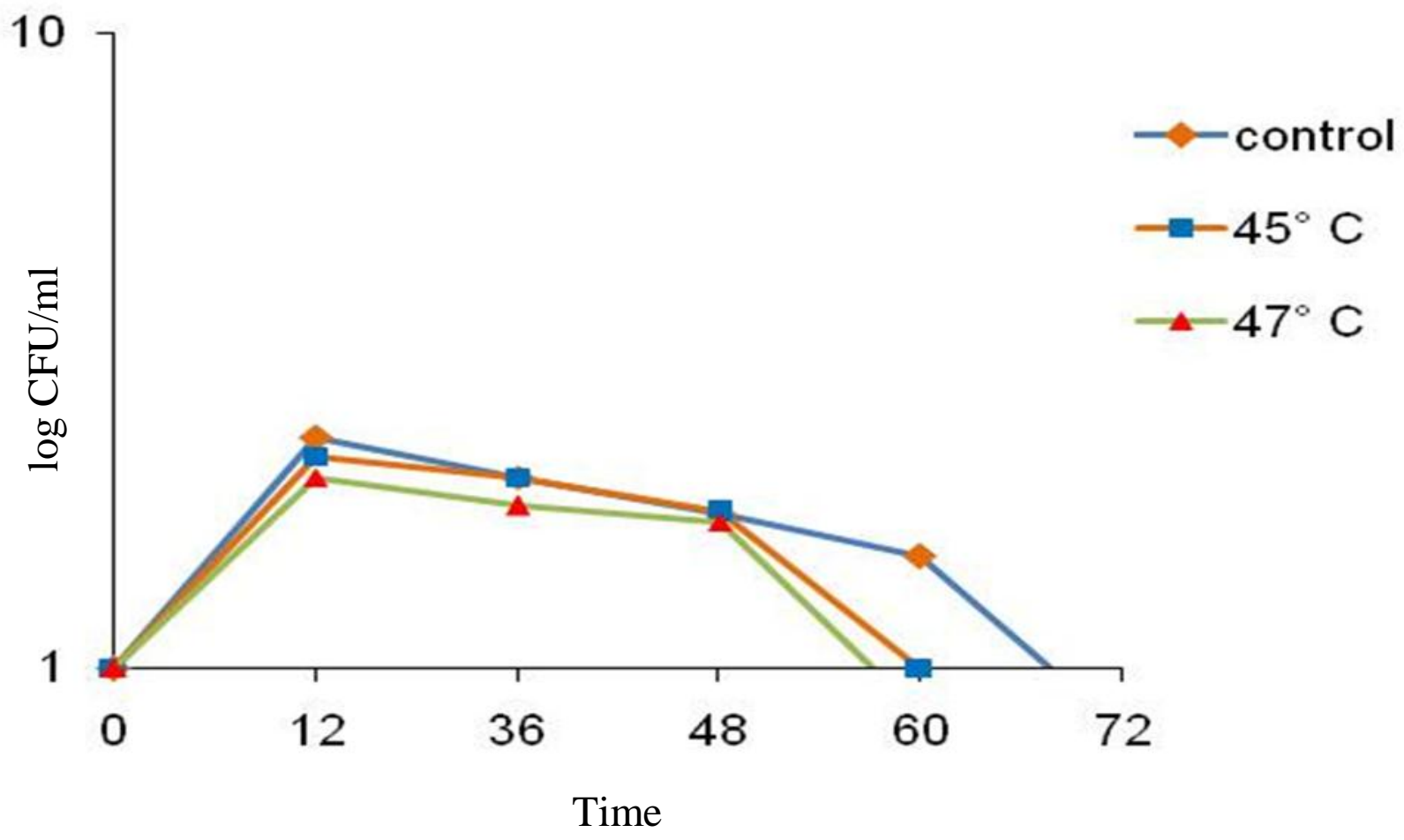

FIG. 1. Assessment of cell culturability through the examination of growth of Escherichia coli upon high temperature treatment. Bacterial cells were grown in nutrient broth at 45 and $47^{\circ} \mathrm{C}$ under $100 \mathrm{rpm}$ as described in Materials and Methods. However, slight variation of growth was observed for both temperature whereas at $45^{\circ} \mathrm{C}$ fecal colifroms exhibited $4 \log \mathrm{cfu} / \mathrm{ml}$ and at $47{ }^{\circ} \mathrm{C}$ it exhibited $3 \log \mathrm{cfu} / \mathrm{ml}$ 


\section{Microscopy of Escherichia coli}

$12 \mathrm{~h} \quad 24 \mathrm{~h} \quad 36 \mathrm{~h} \quad 48 \mathrm{~h} \quad 60 \mathrm{~h} \quad 72 \mathrm{~h}$

$45^{\circ} \mathrm{C}$
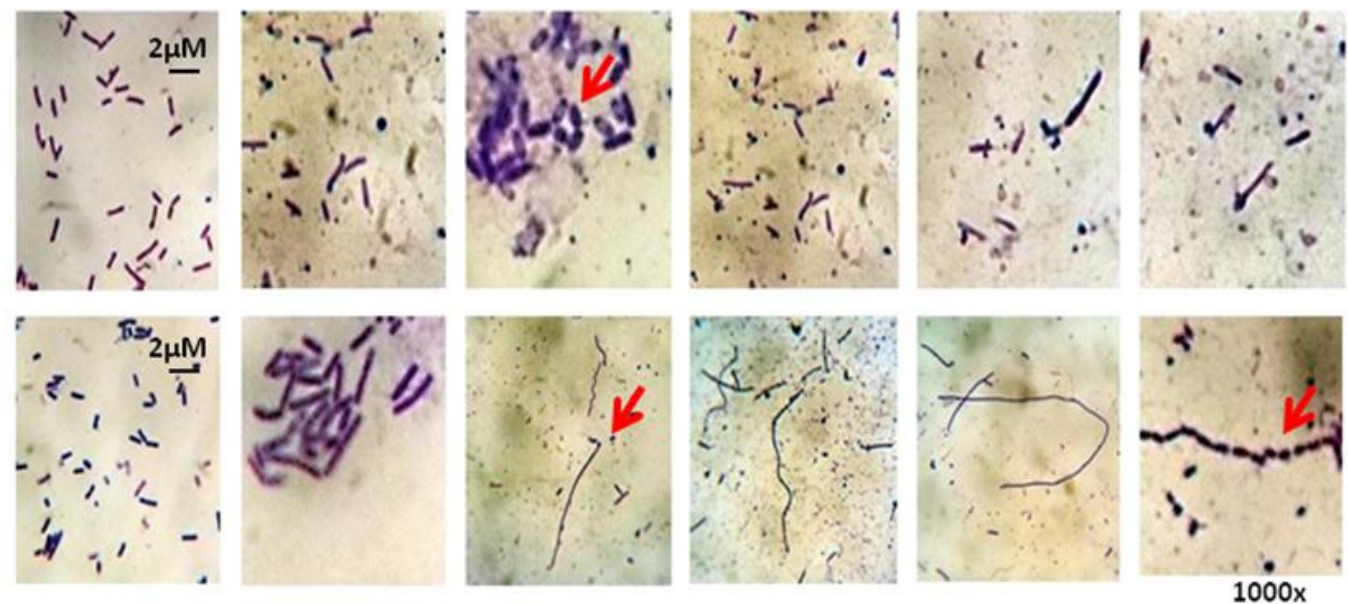

FIG. 2. Morphological examination of Escherichia coli upon temperature treatment. Cells were grown in nutrient broth at 45 and $47{ }^{\circ} \mathrm{C}$ under 100 $\mathrm{rpm}$ as described in Materials and Methods. Cellular morphology and arrangements were observed after 72 hours under microscope at $1000 \mathrm{x}$ magnification, where significant morphological changes were observed.

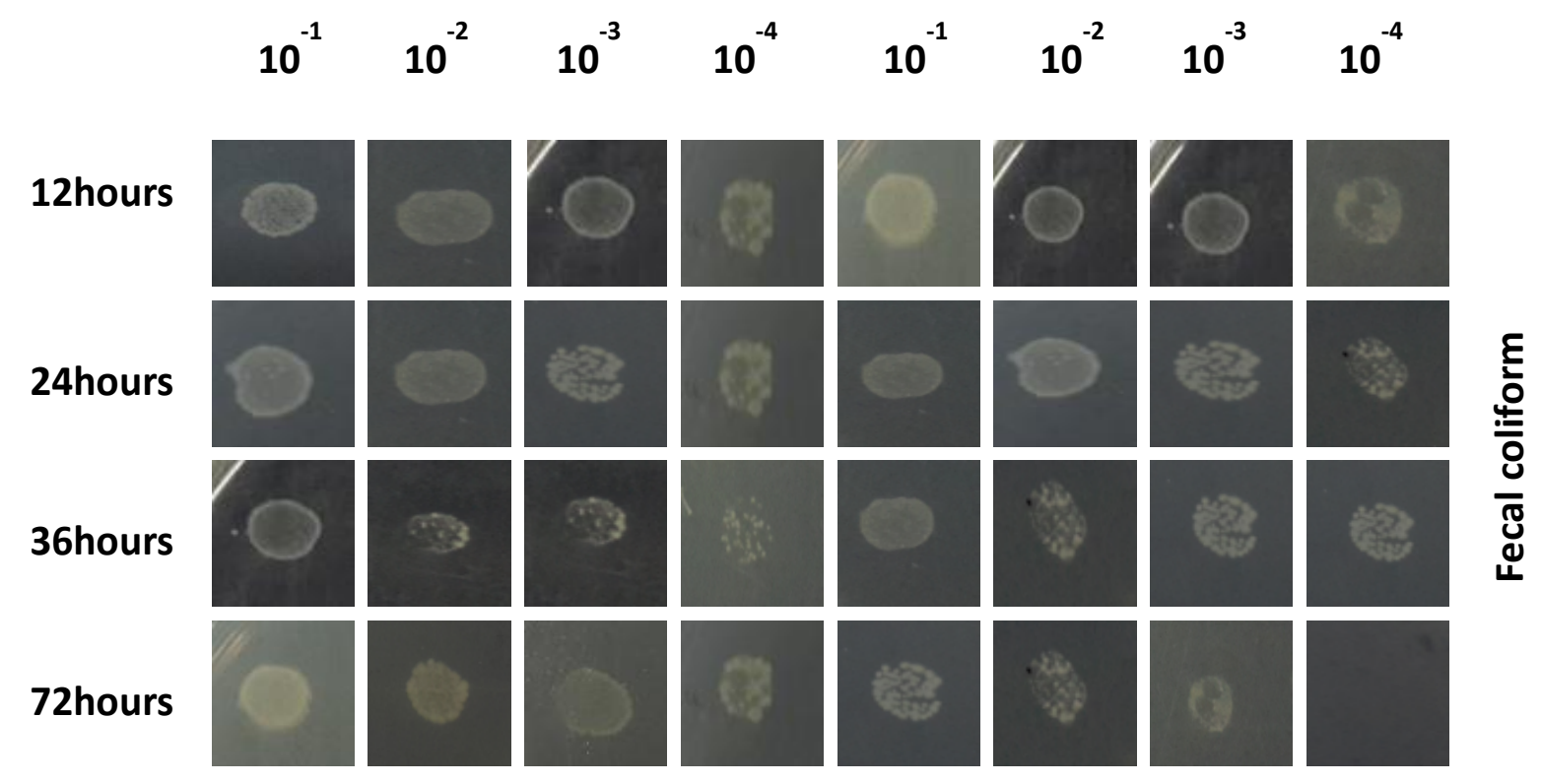

$45^{\circ} \mathrm{C}$

$47^{\circ} \mathrm{C}$

FIG. 3. Confirmative demonstration of culturability and survival potential of Escherichia coli upon temperature treatment. Cells were grown in minimal broth at 45 and $47{ }^{\circ} \mathrm{C}$ under $100 \mathrm{rpm}$ as described earlier. At the times indicated, aliquots of cell culture each consisting of $5 \mu 1$ were used for the spot test as described in Materials and Methods. Notably, from the dilutions up to $10^{-4}$, under both temperatures a growth retardation was observed on the minimal agar. 
environmental reservoirs is only recently being fully appreciated. Variations in temperature range can occur rapidly, which requires an adaptive response for the bacteria to survive. They have shown a range of survival strategies and temperature related changes to the heat stress. Severe morphological change and other property variations like shrinking or elongating and at the later stages breaking down of the threadlike cellular structures was observed in prolonged heat stressed conditions. This is surely a significant finding in the strategies and phenomena and that occur in microorganism's resistance mechanisms against heat stress. This study has been fueled through important information in the related field from previous researches which has worked with defining the effect and mechanism of different stresses including heat shock on certain kind of bacteria. This study has the potential to be studied further which can unveil new and important implications.

\section{ACKNOWLEDGEMENT}

Authors thank Dr. Rashed Noor for his guidance and valuable suggestions during the experiments and manuscript writing. Authors are also thankful to the Microbiology Laboratory, Stamford University Bangladesh, for all the technical help.

\section{REFERENCES}

1. Hecker M, Schumann W, Volker U.1996. Heat-shock and general stress response in Bacillus subtilis. Mol. Microbiol. 19: 417-428.

2. Missiakas D, Mayer MP, Lemaire M, Georgopoulos C, Raina S. 1997. Modulation of the Escherichia coli sigma E (RpoE) heat-shock transcription-factor activity by the RseA, RseB and RseC proteins. Mol. Microbiol. 24: 355-371.

3. Santoro MG. 2000. Heat shock factors and the control of the stress response. Biochem. Pharmacol. 59 (1): 55-63.

4. Ades SE. 2004. Control of the alternative sigma factor sigma E in Escherichia coli. Curr. Opin. Microbiol. 7: 157-162.

5. Kabir MS, Yamashita D, Noor R, Yamada M. 2004. Effect of $\sigma^{\mathrm{S}}$ on $\sigma^{\mathrm{E}}$ directed cell lysis in Escherichia coli early stationary phase. J. Mol. Microbiol. Biotechnol. 8:189-194.

6. McBroom AJ, Kuehn MJ. 2007. Release of outer membrane vesicles by Gram-negative bacteria is a novel envelope stress response. Mol. Microbiol. 63 (2): $545-558$
7. Yamada M, Noor R, Nagamitsu H, Murta M. 2009. The higher temperature, the more oxidative stress and lysis in Escherichia coli. The 3rd international conference on fermentation technology for value added agricultural products, Khon Kaen.

8. Noor R, Murata M, Nagamitsu H, Klein G, Raina S, Yamada M. 2009. Dissection of $\sigma^{\mathrm{E}}$ dependent cell lysis in Escherichia coli: roles of RpoE regulators RseA, RseB and periplasmic folding catalyst Ppid. Genes Cells. 14: 885-899.

9. Murata M, Noor R, Nagamitsu H, Tanaka S, Yamada M. 2012. Novel pathway directed by $\sigma^{\mathrm{E}}$ to cause cell lysis in Escherichia coli. Genes Cells. 17: 234-247.

10. Klein G, Dartigalongue C, Raina S. 2003. Phosphorylation-mediated regulation of heat shock response in Escherichia coli. Mol. Microbiol. 48: 269-285.

11. Guisbert E, Yura T, Rhodius VA, Gross CA. 2008. Convergence of molecular, modeling and systems approaches for an understanding of the Escherichia coli heat shock response. Micro. Mol. Biol. Rev. 72: 545-554.

12. Tang SW, Abubakar S, Devi S, Puthucheary S, Pang T. 1997. Induction and characterization of heat shock proteins of Salmonella typhi and their reactivity with sera from patients with typhoid fever. Infect. Immun. 65: 2983-2986.

13. Periago PM, Schaik WV, Abee T, Wouters JA. 2002. Identification of proteins involved in the heat stress response of Bacillus cereus ATCC 14579. Appl. Environ. Microbiol. 68: 3486-3495.

14. Stockwell VO, Loper JE. 2005. The sigma factor RpoS is required for stress tolerance and environmental fitness of Pseudomonas fluorescens Pf-5. Microbiology. 151: 3001-3009.

15. Heeb S, Valverde C, Gigot-Bonnefoy C, Haas D. 2005. Role of the stress sigma factor RpoS in GacA/RsmA-controlled secondary metabolism and resistance to oxidative stress in Pseudomonas fluorescens CHA0. FEMS Microbiol. Lett. 243: 251-258.

16. Ramos-Gonzalez MI, Molin S. 1998. Cloning, sequencing, and phenotypic characterization of the rpoS gene from Pseudomonas putida KT2440. J. Bacteriol. 180: 3421-3431.

17. Suh SJ, Silo-Suh L, Woods DE, Hassett DJ, West SHE, Ohman DE. 1999. Effect of rpoS mutation on the stress response and expression of virulence factors in Pseudomonas aeruginosa. J. Bacteriol. 181: 3890-3897.

18. Noor R, Murata M, Yamada M. 2009. Oxidative stress as a trigger for growth phase-specific $\sigma^{\mathrm{E}}$ dependent cell lysis in Escherichia coli. J. Mol. Microbiol. Biotechnol. 17: 177-187.

19. Noor R, Islam Z, Munshi SK, Rahman F. 2013. Influence of temperature on Escherichia coli growth in different culture media. J. Pure Appl. Microbiol. 7: 899-904.

20. Murata M, Fujimoto H, Nishimura K, Charoensuk K, Nagamitsu H. 2011. Molecular strategy for survival at a critical high temperature in Eschierichia coli. PLoS ONE. 6: e20063.

21. Munna MS, Tamanna S, Afrin MR, Sharif GA, Mazumder C, Kana KS, et al. 2014. Influence of aeration speed on bacterial colony forming unit (CFU) formation capacity. Am. J. Microbiol. Res. 2 (1): 47-51.

22. Nur I, Munna MS, Noor R. 2014. Study of exogenous oxidative stress response in Escherichia coli, Pseudomonas spp., Bacillus spp. and Salmonella spp. Turk. J. Biol. 38: 502-509.

23. Munna MS. Nur IT. Rahman T. Noor R. 2013. Influence of exogenous 